\title{
9 EXPORTING THE REVOLUTION TO AFRICA: THE NIGERIAN EXPERIENCE
}

\section{Sohail Wahedi ${ }^{1}$}

\section{INTRODUCTION}

Over the past few years, a growing number of African states have rethought their diplomatic relationships with the Islamic Republic of Iran, varying from downgrading the diplomatic ties to complete shutdowns of their diplomatic missions. In May 2018, Morocco decided to cut its diplomatic relationship with Iran, accusing the country of intervening in its internal affairs and supporting terrorism. ${ }^{2}$ This was actually the second suspension of relations, as Morocco also severed its diplomatic relationships in 2009 with Iran, which was accused of spreading Shia ideology in Morocco at that time. ${ }^{3}$ In 2016, Comoros took a similar decision and accused Iran of spreading Shiism in its archipelago of islands. ${ }^{4}$ The same charge was raised against the cultural centres of Iran in Sudan. In 2014, the Sudanese authorities decided to expel Iranian diplomats from Khartoum following accusations of spreading the Shia ideology in Sudan. ${ }^{5}$ In 2016, Djibouti and Sudan cut off all diplomatic relationships with Iran, following the example of Saudi Arabia and Bahrain, which accused Iran of intervening in their internal affairs. ${ }^{6}$ In the same year, Somalia decided to close the Iranian mission in Mogadishu, accusing Iran of supporting terrorism in Somalia. ${ }^{7}$ A few years before, Gambia and Senegal decided to cut off their relationships with Iran, claiming that Iran was in charge of supporting rebellion groups in both countries. ${ }^{8}$

1 PhD candidate, Erasmus School of Law. Research for this chapter is made possible by the Erasmus School of Law Innovation Programme Research and Erasmus Trustfonds.

2 "Morocco cuts diplomatic ties with Iran over Western Sahara feud", Al Jazeera, 1 May 2018.

3 Ghanmi L. 2009. "Morocco cuts ties with Iran over Bahrain", Reuters, 6 March 2009 (reporting on the Moroccan cut in the relationship with Iran, accusing the country of spreading the Shia belief, which allegedly threaten societal harmony).

4 "Comoros shuts down Iran fronts for 'spreading Shi'ism"', Middle East Monitor, 18 January 2017.

5 Abdel Aziz K. 2014. "Sudan expels Iranian diplomats and closes cultural centres", The Guardian, 2 September.

6 "Djibouti cuts ties with Iran after attacks on Saudi missions", Reuters, 6 January 2016; "As economy crumbles, Sudan ditches Iran for Saudi patronage", Reuters, 12 January 2016.

7 "Somalia cuts diplomatic ties with Iran over national security concerns", Goobjoog News, 7 January 2016.

8 Vatanka A. 2016. "Iran's Awkward Diplomacy in Africa", The National Interest, 23 March; Hammond J. 2013. "The Dakar Dance: Tumultuous Iran-Senegal Relationship Enters New Chapter", Diplomatic Courier, 6 March. 
The large scale of the expulsion of Iranian diplomats from Africa, reveals that there is something more going on than a mere diplomatic dispute about spreading Shiism. Indeed, the number of identical closures of embassies, cultural missions and other Iranian outposts is way too high to frame the unusual diplomatic tensions between African countries with a significant Muslim population and Iran as coincidence. The arguments used to suspend the relationships are similar: (1) Iranian interference with the internal affairs of African countries via Iran's support of terrorism and (2) the spread of the Shia ideology across Africa via the creation and military support of "subordinated" groups, who are encouraged to enforce a power change in their country and the region. ${ }^{9}$ Therefore, the mass expulsion of Iranian diplomats fits a pattern of real worries about human security, societal harmony and peaceful coexistence in diversity amongst citizens of the African continent. African states with large Sunni Muslim populations, including many of those mentioned above, which have suspended their diplomatic ties with Iran, seem to be especially vulnerable to foreign policies of Iran. These policies of "exporting the Iranian revolution" outward have clearly destabilised the region economically, politically and socially through supporting local militant groups, such as the Nigerian Hezbollah lookalike Hurra, fighting local authorities, and the establishment and support of small Shia communities that are strongly involved in supporting the local resistance against the authorities. ${ }^{10}$ Moreover, regional developments, such as the ongoing conflicts in the Middle East and Northern Africa region, have uncovered the dangerous role of the Iranian authorities in those regional conflicts. ${ }^{11}$ The most recent United States State Department Country Reports on Terrorism from 2017 reveal that Iran has remained "the world's leading state sponsor of terrorism", creating and supporting Shiite military groups in the Middle East and far outside this region. ${ }^{12}$

Over the recent years, influential regional organisations have raised concerns about the consequences of the Iranian activities for peace and stability in the Middle East and Africa. ${ }^{13}$ This concern has been expressed explicitly by the Organisation of Islamic Cooperation (OIC), which has repeatedly condemned Iran for its policies of "interference" and called upon Iran "to discontinue any policies susceptible to fuel ethnic or sectarian disputes and to desist from supporting or financing the terrorist factions and movements". ${ }^{14}$ This criticism may seem to be a sectarian condemnation, as it singles out Iran while leaving aside comparable policies of interference

9 Neriah J. 2013. “Iranian Shiite Terror Cell in Nigeria Followed a Familiar Pattern”, Jerusalem Issue Briefs 13(6).

10 Zenn J. 2013. "The Islamic Movement and Iranian Intelligence Activities in Nigeria", Combatting Terrorism Center Sentinel 6(10):13-18.

11 International Crisis Group. 2018. “Iran's Priorities in a Turbulent Middle East, Middle East Report, No. 184.

12 U.S. Department of State Publication. 2018. "Country Reports on Terrorism 2017".

13 Karagiannis E. 2016. "The rise of Iran as a regional power: Shia empowerment and its limits", NATO Review.

14 Resolution No. 46/45-POL “on the attack against the Kingdom of Saudi Arabia's Embassy in Tehran and Consulate in Mashhad" (OIC/CFM-45/2018/POL/RES/FINAL); repeated in 
adopted by other states, such as Saudi Arabia. ${ }^{15}$ However, the empirical evidence suggests that over the past few decades Iran has been very active in spreading the Shia ideology, specifically "Khomeinism", 16 and distributing violence across the region through supporting terrorism and rebellion groups. ${ }^{17}$ This violent and sectarian policy of destabilisation, based on political hegemony ambitions of Iran, has devastating consequences for human flourishing - understood as satisfaction about crucial goods in life ${ }^{18}$ - across many African countries, ${ }^{19}$ with the precarious situation in the northern part of Nigeria as most egregious example in this context. ${ }^{20}$ In this region, paramilitary groups have attacked the authorities and attempted to create a mini-state inside the state, ${ }^{21}$ strongly modelled upon the way Hezbollah governs areas in Lebanon. ${ }^{22}$ It needs little explanation that such interference is quite unacceptable for any government in the targeted countries.

Therefore the main aim of this chapter is to set forth the dangers of Iranian interference in other countries through the "export of its revolution" outward. More specifically, this chapter focuses on how such interference has affected human flourishing in areas related to peaceful coexistence, property safety and human security. ${ }^{23}$ This chapter starts with a brief description of the "export of revolution" doctrine and Iranian policies related to this. It then directs attention to a particular case of violence and insecurity that has been directly linked to policies based on the "export of revolution" doctrine. This concerns the rise of the Islamic Movement in Nigeria, as led by Ibrahim Yaqoub El-Zakzaky, and its continuous strife against the

the same resolution in 2017 (OIC/CFM-44/2017/POL/RES/FINAL) and 2016 (OIC/CFM43/2016/POL/RES/FINAL).

15 Garba AS. 2018. "The Prospects and Problems of the Marrakesh Declaration on the Rights of Religious Minorities in predominantly Muslim Majority Communities", The Review of Faith E International Affairs 16(4):47-59.

16 Zenn J. 2013. "The Islamic Movement and Iranian Intelligence Activities in Nigeria", CTC Sentinel 16(10):13-18.

17 Bar S. 2009. "Iranian Terrorist Policy and 'Export of Revolution'”, Working Paper, Interdisciplinary Center Herzliya, Lauder School of Government, Diplomacy and Strategy Institute for Policy and Strategy.

18 Barnett RE and Rasmussen DB. 2001. "The Right to Liberty in a Good Society", Fordham Law Review 69(5):1603-1615.

19 Avriel G. 2015. "Terrorism 2.0: The Rise of the Civilitary Battlefield", Harvard National Security Journal 7(1):199-240.

20 Anjide ST and Al Chukwuma O. 2017. "New Trajectory of Islamic Extremism in Northern Nigeria: A Threat-Import Analysis of Shiite's Uprising", International Journal of African and Asian Studies 32:41-51.

21 Egbewole WO and Hammed HA. 2018. "Curbing religious extremism of Boko Haram insurgency in Nigeria", in Green MC, Gunn TJ and Hill M (eds). Religion, Law and Security in Africa. Stellenbosch: AFRICAN SUN MeDIA, 3-19.

22 Wege CA. 2012. "Hizballah in Africa", Perspectives on Terrorism 6(3):45-56.

23 Barnett and Rasmussen, "The Right to Liberty in a Good Society" (elaborating on the concept of human flourishing and its various facets). 
federal authorities. ${ }^{24}$ This group has succeeded in creating a large Shia minority in Nigeria and many other African states, such Ghana, Kenya and Tanzania, which counted hardly any Shia in their Muslim populations before the Iranian revolution in $1979 .{ }^{25}$ The final focus of the chapter is on the way policies based on exporting the revolution doctrine have affected human flourishing in vital areas of life causing many and irreparable damages to human security, prosperity and harmony. ${ }^{26}$

The conclusion of this chapter is that the "export of revolution" doctrine and the policies based hereon, particularly religious conversion policies, should not be assessed from a tolerant religious freedom lens. Support for militant groups that undermine the authority of the local government seeking for the establishment of a new religious order is unacceptable. ${ }^{27}$ The serious negative consequences of "exporting of revolution" to other states and regions urge us to assess this doctrine as a serious security matter that endangers human flourishing. The Nigerian situation is probably the best case reaffirming this concern. In Nigeria, both human beings and weapons have been utilised by Iranian authorities to gain power in Africa. ${ }^{28}$ Iran has used conversion policies to create a group that can fight the local authorities, and it has provided them subsequently with the necessary weapons and means to achieve that goal. ${ }^{29}$

\section{THE EXPORT OF REVOLUTION TO AFRICA}

Early 1979, the clergy came to power in Iran in a quite revolutionary step that marked the end of a long tradition of monarchy in Persia. ${ }^{30}$ They established a theocracy based on Shia Ja'fari jurisprudence, with Ayatollah Khomeini as the religious leader. ${ }^{31}$ The change of powers in Iran not only influenced the life of

24 Kendhammer B. 2016. Muslims Talking Politics: Framing Islam, Democracy, and Law in Northern Nigeria. London: The University of Chicago Press, 106.

25 Hunter ST. 2010. Iran's Foreign Policy in the Post-Soviet Era: Resisting the New International Order. Oxford, UK: Praeger, 227.

26 Berman I. 2015. Iran's Deadly Ambition. New York, YK: Encounter Books.

27 Mukasey MB. 2017. "Judicial Independence: The Fortress Threatened from within", University of Memphis Law Review 47(4):1223-1234 (arguing that security concerns prevail over religious).

28 Mickolous E. 2016. Terrorism, 2013-2015: A Worldwide Chronology. Jefferson: McFarland \& Company Inc. Publishers, 543 (reporting on how Mustapha Berende, a local Shia leader who got military training in Iran, supervised training of paramilitary groups in Nigeria and called for attacks on the Sultan of Sokoto and former army general Ibrahim Babangida).

29 Alami M. 2018. "Hezbollah allegedly training Nigerian Shiites to expand influence in West Africa", Middle East Institute, 5 July.

30 Milani A. 2013. The Myth of the Great Satan: A New Look at America's Relations with Iran. Stanford: Hoover Institution Press, 81.

31 Ajami F. 1988. “Iran: The Impossible Revolution”, Foreign Affairs 67(2):135-155. 
people living inside the country, ${ }^{32}$ but also affected people's lives far outside Iran. ${ }^{33}$ The main reason for this was that the new rulers adopted a sectarian approach to dispatch their internal and external affairs. ${ }^{34}$ This section of the chapter thus starts with a brief discussion of how the 1979 Revolution affected the life of people living inside Iran. Given the limited space of this chapter, the focus will be on religious freedom. It then focuses on how Iranian authorities have used religion to reinforce their political hegemony in the region. ${ }^{35}$

The post-revolutionary Constitution of the Islamic Republic of Iran codified a sectarian version of "religious freedom". Articles 12 and 13 of the Constitution exhaustively enumerate religions that are allowed to practise their faiths within the legal framework of the Islamic Republic. The "recognised" religions include Zoroastrianism, Judaism and Christianity. The Shia Ja'fari School of jurisprudence has been recognised as the "eternally immutable" religion of the Iranian state. The establishment of this Shia theocracy and its enactment in the Iranian constitution effectively resulted in the enactment of a "Shiacracy" - a democracy for the people who follow the official line of state's religious doctrine, but also a Shia ethnocentric identity aversion towards "infidels", those who do not fit the official state religion. In the aftermath of the revolution, Iranian officials introduced a number of mechanisms to eliminate all beliefs that could potentially harm the official line of belief. ${ }^{36}$ These mechanisms included the establishment of the Revolutionary Court, ${ }^{37}$ a Revolutionary Guard Corps - paramilitary force defending inside and outside Iran the interests of the regime, ${ }^{38}$ and the Basij - another paramilitary group that is on a voluntary basis in charge of enforcing all kind of moral rules. ${ }^{39}$ What proved very effective in this regard was the establishment of the Special Clerical Court. ${ }^{40}$

32 Axworthy M. 2013. Revolutionary Iran: A History of the Islamic Republic. Oxford: Oxford University Press.

33 Congressional Research Service Report. 2019. "Iran's Foreign and Defense Policies".

34 Negahban B. 2017. “Who Makes Iran's Foreign Policy: The Revolutionary Guard and Factional Politics in the Formulation of Iranian Foreign Policy", Yale Journal of International Affairs 12:33-48 (on the role the Islamic Revolutionary Guard Corps plays to defend the revolution inside Iran and support revolutionary sources outside Iran).

Wehrey FM. 2014. Sectarian Politics in the Gulf: From the Iraq War to the Arab Uprisings. New York: Columbia University Press, 21 (paying attention to the Iranian role).

36 Beres LR. 1996. "Israel, Iran, and Nuclear War", UCLA Journal of International Law $\mathcal{E}$ Foreign Affairs 1(1):70 (on how a local Revolutionary Court judge called on the complete elimination of the adherents of the Bahá'í faith).

Nelson SC. 1990. “Human Rights in Iran”, International Lawyer 24(2):607-614, 612 (outlining the law-free zone in which Revolutionary Courts operate without any safeguard for a fair trial).

38 Negahban, "Who Makes Iran's Foreign Policy".

39 Ganji A. 2008. “The Latter-Day Sultan. Power and Politics in Iran”, Foreign Affairs 87(6):56.

40 Künkler M. 2013. "The Special Court of the Clergy (Dädgāh-Ye Vizheh-Ye Ruhāniyat) and the Repression of Dissident Clergy in Iran", in Arjomand SA and Brown NJ (eds). Rule of Law, Islam, and Constitutional Politics in Egypt and Iran. Albany: State University of New York Press, 57-100. 
In the post-revolution era, the Special Clerical Court has dismissed numerous highly respected Grand Ayatollahs from clergy, such as Ayatollah Shariatmadari, ${ }^{41}$ and imprisoned indefinitely many others, like Ayatollah Kazemeini Boroujerdi, ${ }^{42}$ both critical of concentration of power by the clergy. Furthermore, it has limited the space for others, such as the late Grand Ayatollah Montazeri - who had been very critical of the Revolutionary Courts and the Special Clerical Courts ${ }^{43}$ - to raise their voice against injustice and other inconveniences. ${ }^{44}$ But, since the revolution, the Shia school of belief has undergone significant and unprecedented changes. ${ }^{45}$ In this respect, the empowerment of the clergy and the bureaucratisation of the Shia religion, ${ }^{46}$ have shaped the right conditions to eliminate all expressions of religious beliefs and manifestations that are contrary to the official line of belief. ${ }^{47}$ Consequently, not only are many religious minorities suffering from an unfree atmosphere, $^{48}$ but Shia jurisprudence, as such, is also in danger, ${ }^{49}$ as many Shia scholars who think in an opposite way are prosecuted, imprisoned and in some cases even sentenced to death. ${ }^{50}$ Furthermore, many Iranian Shias have decided to turn away from Shiism because of the oppression and lack of freedom they suffer from authorities who justify each action and intervention on the Shia jurisprudence. ${ }^{51}$ But apart from this unique way of civil resistance, what is all the most striking in this regard is the fact that the Iranian Constitution recognises in Articles 12 and 13 a discriminatory version of religious freedom, since not all religious groups enjoy equal treatment. ${ }^{52}$

41 Sherrill CW. 2018. Losing Legitimacy. London: Lexington Books, 51.

42 Sarkissian A. 2015. The Varieties of Religious Repression. Oxford: Oxford University Press, 57.

43 Tamanaha BZ. 2007. "The Contemporary Relevance of Legal Positivism", Australian Journal of Legal Philosophy 32:16 (quoting Ayatollah Montazeri about the Special Courts).

44 Sciolino E. 2000. Persian Mirrors: The Elusive Face of Iran. New York: The Free Press, 197 (on how the Special Clerical Court created restrictions upon spreading the messages of Ayatollah Montazeri).

45 Khalaji M. 2010. The New Order of the Clerical Establishment in Iran. Buchum: Aida Book.

46 Khalaji M. 2011. "Iran's Regime of Religion", Journal of International Affairs 65(1):131-147.

47 Menashri D. 2001. Post-Revolutionary Politics in Iran: Religion, Society and Power. New York: Routledge.

48 Garba, "The Prospects and Problems of the Marrakesh Declaration on the Rights of Religious Minorities in predominantly Muslim Majority Communities".

49 Abdo G. 2017. The New Sectarianism. Oxford: Oxford University Press, 19. See also Tamadonfar M. 2001. "Islam, Law, and Political Control in Contemporary Iran", Journal for the Scientific Study of Religion 40(2):205-220.

50 Afshari R. 2001. Human Rights in Iran: The Abuse of Cultural Relativism. Philadelphia: University of Pennsylvania Press, 217 (on the authorities' approach towards religious dissidents).

51 Khalaji M. 2013. “The Rise of Persian Salafism”, Washington Institute for Near East Policy, 3 October 2013 (reporting on how many Iranians have decided to leave Shiism and convert to Bahá'ísm, Sunnism and Christianity as a sign of protest against the rulers).

52 Cohen JF. 2008. "Islamic Law in Iran: Can it Protect the International Legal Right of Freedom of Religion and Belief", Chicago Journal of International Law 9(1):247-274 (paying, 
For example, in the post-revolution era, the Bahá'í faith is outlawed. The adherents of this religion have been persecuted and many are sentenced to death by the special tribunals on accusations of conspiracy and espionage. ${ }^{53}$ The Sunni religious minority, which is recognised as a religious minority by the Iranian constitution, has faced legal obstacles to building places of worship. In fact, Tehran is the only capital in the entire Islamic world that has prohibited Sunni Muslims from having their own mosque, and the de facto mosques have been demolished by official state actors. ${ }^{54}$ Furthermore, Sunni Iranians are prohibited from running for presidential elections and they face serious discrimination in all other areas of life. ${ }^{55}$ The Islamic Revolution of Iran, which started with promises of welfare, civil liberties and political freedoms, in fact has established a religious autocracy ruled by the ultimate Islamic arbiter in the society, the so-called Valiyeh Faqih, the highest learned religious authority, whose position is justified by the doctrine of the Velayat-e Faqih that focuses on the governance aspects of the Islamic jurist. ${ }^{56}$ However, the concept of Velayat-e Faqih is a highly contested religious doctrine within the Shia school of belief. ${ }^{57}$

The paradigmatic shift of powers in Iran, from a light constitutional monarchy to a Shia theocracy, not only resulted in the legalisation of discrimination against religious minorities and the religious persecution of all those who did not belong to the official line of belief; ${ }^{58}$ the new theocracy, with its sectarian approach to the "others", also started in the immediate aftermath of the revolutionary victory to export its ideology to other places around the globe. Khomeini, the leader of the Iranian Revolution, started in the early days of the new regime to back the strife of Shia leaders in neighbouring countries such as Iraq, Kuwait and Bahrain, ${ }^{59}$ and encouraged those leaders to fight for institutional changes, as had happened in Iran. ${ }^{60}$ Scholars have said that serving as a role model for other nations seeking a similar "Islamic" change of power like Iran, was more important to Khomeini than

amongst others, attention to the suffering of members of the Sunni community in Iran, facing discrimination and hatred).

Ghanea N. 2002. Human Rights, the UN and the Bahá'ís in Iran. The Hague: Kluwer Law International, 288.

Alijani E. 2015. “Tehran's authorities destroy Sunni worship space”, France 24, 8 June.

Garba, "The Prospects and Problems of the Marrakesh Declaration on the Rights of Religious Minorities in predominantly Muslim Majority Communities".

56 Mavani H. 2011. "Ayatullah Khomeini's Concept of Governance (wilayat al-faqih) and the Classical Shi'i Doctrine of Imamate", Middle Eastern Studies 47(5):807-824.

57 Zahedi D. 2001. The Iranian Revolution Then and Now. Colorado: Westview Press, 70.

58 United States Department of State. 2016. "International Religious Freedom Report for 2016", 16 (on the religious persecution of the members of the Bahá'i community, the Yarsani believers and followers of the Mandaean faith).

59 Ulrichsen KC. 2015. Insecure Gulf: The End of Certainty and the Transition to the Post-oil Era. Oxford: Oxford University Press.

60 Central Intelligence Agency. 1979. Iran: The Shia Revolution and Iran's Neighbors. 
improving the economy or realising other promised changes, for example, in the field of governance at home. After all, Khomeini saw himself as the undisputed leader of the whole Islamic community. ${ }^{61}$ But, what does "export of revolution" entail? And, what means have been used to realise it?

Basically, the "export of revolution" stands for the support of others' struggle to realise a change of power generally. ${ }^{62}$ More specifically, it is all about backing the strife of Islamist fighters with a Shia background, ${ }^{63}$ and this support goes back to the very beginning days of the Islamic republic. ${ }^{64}$ Thus, it is all about "revolutionary internationalism", 65 with an emphasis on the struggle of Shiite groups across the world. ${ }^{66}$ According to the late University of Virginia professor emeritus of foreign affairs, Rouhollah Ramazani, the "export of revolution" has the same international relation narrative as the more familiar notions of "intervention" and "invasion". For example, some countries, such as the United States, intervene to spread democracy. Other states, like the Soviet Union invade to spread socialism. In a similar way, Iran exports its revolution outward to spread its own version of the Islam. According to Ramazani, the export of revolution became a major principle shaping the contours of Iran's foreign policy. ${ }^{67}$ This principle is rooted in an ideological aversion to "Western" hegemony, legitimising the strife of "subordinated" groups around the globe. ${ }^{6}$ More concretely, Iranian authorities gathered revolutionary forces from other places, such as Iraq, Lebanon and Bahrain, and put them in the Islamic Revolutionary Council, which cooperated closely with the Iranian Islamic Revolutionary Guard Corps, which the Iranian Constitution has the tasked with reinforcement and establishment of Islamic states all around the globe. ${ }^{69}$

61 Rakel EP. 2007. "Iranian Foreign Policy since the Iranian Islamic Revolution: 1979-2006", in Amineh MP (ed). The Greater Middle East in Global Politics. Leiden: Brill, 147-175.

62 For example, Iran has supported the struggle of "subordinated" groups in Latin America. See Levitt M. 2015. "Iranian and Hezbollah Operations in South America: Then and Now", PRISM 5(4):119-133.

63 For example, in Afghanistan, see Emadi H. 1995. “Exporting Iran's Revolution: The Radicalization of the Shiite Movement in Afghanistan", Middle Eastern Studies 31(1):1-12.

64 Central Intelligence Agency. 1980. Iran: Exporting the Revolution.

65 Ostovar A. 2016. Vanguard of the Imam. Religion, Politics, and Iran's Revolutionary Guards. Oxford: Oxford University Press, 104.

66 Salamey I and Othman Z. 2011. "Shia Revival and Welayat Al-Faqih in the Making of Iranian Foreign Policy", Politics, Religion \& Ideology 12(2):197-212, 201.

67 Ramazani RK. 2013. Independence without Freedom. Charlottesville/London: University of Virginia Press, 128.

68 See, for example, Sadri HA. 1998. "Trends in the foreign policy of revolutionary Iran", Journal of Third World Studies 15(1):13-37 (discussing how, in the post-revolution, foreign policy was based on the foreign policy choices of the former Shah of Iran, aiming at framing him as an incapable man to guide his nation).

69 Ramazani, Independence without Freedom 132. 
Effectively, the foreign policy of Iran with its focus on exporting the revolution to other places reinforced Shiism in an unprecedented way. It is widely believed that the post-revolution era heralds the revival of Shiism. ${ }^{70}$ Not in the last place because of the spread of this belief via Iran, which has developed effective conversion policies to change the political and religious landscape outside Iran. ${ }^{71}$ Furthermore, it has supported Shia groups to increase its political hegemony outside Iran, particularly in its neighbouring countries, such as Bahrain and Iraq. ${ }^{72}$ Concrete examples are the Iranian support of terrorist groups such as the Hezbollah in Lebanon and the creation of Hezbollah lookalike faction in many countries across Africa, Asia and the Middle East. ${ }^{73}$

In this respect, spreading and preserving the Iranian post-revolution style Shia ideology is the main ambition of Iran in its foreign policy regarding countries that potentially provide room for its spread. ${ }^{74}$ Effectively, as the Washington Institute for Near East Policy has reported,

Iran uses Shiism as the main tool to attract foreigners to cooperate in its undertakings. In countries where Shia populations have felt threatened, Tehran presents itself as a savior, supporting "resistance" movements with arms and money. In countries where Shiism is not present, Iran has invested resources in spreading Shiism and converting the local population, with Nigeria's Shia community, currently numbering in the millions, serving as the best such example. ${ }^{75}$

How can we understand this policy? What does provide a base for exporting the revolution to other places? At the outset, what needs to be emphasised here, is that the "export of revolution" has a much broader narrative than the international relations frame, as already discussed. ${ }^{76}$ To theorise this specific foreign policy, we can also draw inspiration from an important religious doctrine of the Iranian regime's version of Shiism, which aims at accelerating the return of the legendary hidden and twelfth imam of the Shia believers: the Mahdi. ${ }^{77}$

70 Salamey and Othman, "Shia Revival and Welayat Al-Faqih in the Making of Iranian Foreign Policy".

71 Trofimov Y. "With Iran-Backed Conversions, Shiites Gain Ground in Africa", Wall Street Journal, 12 May 2016 (on how Iran conversion policies have resulted in the creation of Shia communities in Africa); "Iran and the Shia legacy", Al Jazeera, 1 February 2009 (providing detailed information about the conversion activities of Iran across the Middle East and Africa).

72 Ramazani, Independence without Freedom. See also Ostovar. Vanguard of the Imam. Hanna MW and Kaye DD. 2015. “The Limits of Iranian Power”, Survival 57(5):173-198, 176. Abdo, The New Sectarianism, 147. Carmi O. 2017. "Deconstructing and Countering the Iran Threat Network", The Washington Institute for Near East Policy.

76 Ramazani, Independence without Freedom.

77 Khalaji M. 2008. "Apocalyptic Politics. On the Rationality of Iranian Policy", The Washington Institute for Near East Policy. 
But from a legal perspective, it is worthy to mention that in the post-revolution era the legislator decided to provide a legal base for the "export of revolution". ${ }^{78}$ As such, the preamble of the Constitution of the Islamic Republic of Iran clarifies the mission of the Iranian regime. It proclaims the unambiguous mission of Iran's regime: that is creating the right conditions for a "continuation of the Revolution at home and abroad". ${ }^{79}$ Furthermore, the preamble says that the Iranian Army and its Revolutionary Guard "will be responsible not only for guarding and preserving the frontiers of the country, but also for fulfilling the ideological mission of jihad in God's way; that is, extending the sovereignty of God's law throughout the world". ${ }^{80}$ Although, the constitution talks in terms of "Support of Just Struggles", without clarifying what this "just struggle" is, it is clear from the text of Article 154 of the Iranian Constitution that Iran has the disturbing ambition to support "the just struggles of the freedom fighters against the oppressors in every corner of the globe" .81

Hence, the question is, how shall we appraise Iran's ambition to export its revolution? Does that mean converting others to the Iranian regime's version of Shiism? Thus, is the export of revolution a proselytisation strategy adopted by Shia hardliners in Iran $?^{82}$ Or, is the doctrine behind this idea broader than simply, what we may call the "Shiatisation" of the region? ${ }^{83}$ What is however clear over the recent years is that Iran has the unambiguous ambition to expand its influence and hegemony beyond its own territories. As such, it has helped the Shia Hezbollah groups in Lebanon to create a state inside a state. ${ }^{84}$ Iran has helped the Shiite opposition groups against the Saddam regime in Iraq and more recently it has supported rebellion groups that were fighting at the side of Bashar al-Assad in Syria. ${ }^{85}$ Evidence shows that Iran has created Shiite groups of fighters from Afghanistan and Pakistan to fight against

"Exporting the Revolution in Iran's constitution and the Mahdi's return", Track Persia, 16 May 2017.

79 Camara FK. 2010. "States and Religions in West Africa: Problems and Perspectives", in Ferrari S and Cristofori R (eds). Law and Religion in the 21st Century. New York: Routledge, 45.

80 Mayer E. 2018. Islam and Human Rights: Tradition and Politics. New York: Routledge.

81 Article 154, Constitution of the Islamic Republic of Iran.

82 See Leichtman MA. 2009. "Revolution, Modernity and (Trans)National Shi i Islam: Rethinking Religious Conversion in Senegal", Journal of Religion in Africa 39(3):319-351 (on how, in the post-revolution era, the Iranian regime has succeeded in creating a pro-Iranian Shia community in Senegal that advances the Iranian agenda in that region).

83 See, for example, Milani MM. 2009. "Understanding Iran's U.S. Policy", Foreign Affairs 88(4):46-62 (saying that much of Iran's contemporary foreign policy draws on the strategy of neutralising the influence of the United Sates on the Middle East, via creating support in the very heart of the Sunni Arab world, through helping those advancing the Iranian agenda).

84 Abdul-Hussain H. 2009. "Hezbollah: A State within a State", Current Trends in Islamist Ideology 8:68-81.

Ostovar. Vanguard of the Imam. 
the predominantly Sunni opposition groups in Syria. ${ }^{86}$ As Omer Carmi from the Washington Institute for Near East Policy has rightly highlighted in a recent policy note, since the 1979 Islamic Revolution:

Tehran sought to export its ideology abroad, hoping to found "extensions" of the Islamic Republic. Iran sponsored Shia populations, urging them to form militant and political groups that shared the regime's ideology of velayat-e faqih (rule of the jurisprudent) and were willing to work with Tehran to achieve common goals. Those groups, such as Hezbollah in Lebanon, remain aligned with Iran's interests in the Middle East, and their decision making process is heavily influenced by Iran, to the extent that Iranian operatives are active partners in such decision making. In return, Tehran supports its proxies with arms, money, advice, and state-level backing. ${ }^{87}$

This way of supporting opposition groups abroad that are in favour of Iranian policies with money and weapons has its roots in politics as well as religion.

More importantly, Iran has succeeded very much in creating pro-Iranian regime hubs far outside Iran, ${ }^{88}$ not only in the Middle East, ${ }^{89}$ but also in Latin America, ${ }^{90}$ and Africa. In what follows we will focus on how Iran succeeded to gain support for its agenda in Africa and how this support has affected human flourishing. We will mainly focus on the unique situation in Nigeria that faces serious threats. ${ }^{91}$ These threats are amongst others coming from Iran that has the ambitions to export its revolution to the African continent. ${ }^{92}$ Today, Nigeria is believed to be the only region outside the Middle East where the Iranian influence is visible so immense..$^{93}$

\section{THE RISE OF THE ISLAMIC MOVEMENT IN NIGERIA}

How does the Iranian promise to support the "just struggle" play out abroad? More specifically, do we have any proof of Iranian attempts to export the revolution to African states? In fact, we do have strong evidence that shows how Iranian forces have actively attempted to export their revolution to African states with a large Sunni Muslim population. ${ }^{94}$ At least in one case, there is an overwhelming amount of

86 Carmi, "Deconstructing and Countering the Iran Threat Network".

87 Carmi, "Deconstructing and Countering the Iran Threat Network".

88 See, for example, the analysis of Bar S. 2009. "Iranian Terrorist Policy and Export of Revolution". Paper presented at the Ninth Annual Herzliya Conference on the Balance of Israel's National Security and Resilience, Herzliya, Israel. Bar argues that Khomeini framed his message in an ecumenical way so that both factions of the Islam would join him.

See, generally, Ostovar. Vanguard of the Imam.

Levitt, "Iranian and Hezbollah Operations in South America: Then and Now".

Egbewole and Hammed, "Curbing religious extremism of Boko Haram insurgency in Nigeria".

Alami, "Hezbollah allegedly training Nigerian Shiites to expand influence in West Africa".

Zenn, "The Islamic Movement and Iranian Intelligence Activities in Nigeria".

"Iran and the Shia legacy", Al Jazeera. 
evidence of the active Iranian support for the spread of Shiism, the military training of civilians and supporting the militant resistance of local people against their rulers. This country in question is Nigeria, which has dealt with serious security challenges caused by Iran's ambitions to gain power in West-Africa, particularly in the rise of the Islamic movement in Nigeria and the growing local anarchy and violence in Nigeria's northern states. ${ }^{95}$ The insecure situation in that area culminated in 2015 after heavy clashes in the Kaduna State between Nigerian Shias and the security forces. ${ }^{96}$ Over the past few decades, Iran has actively supported the "oppressed" Shia minority in northern Nigeria with arms and money, presenting itself as a real saviour of this community. This support has resulted in the creation of a large Shia minority in a country that had hardly any Shia in the past. ${ }^{97}$ The main aim of this support has been the creation of a state within a state, as so as in the case of the Hezbollah in Lebanon, ${ }^{98}$ to gain power in Africa. ${ }^{99}$

The Iranian attempts to spread Shiism in Nigeria date back to the beginning years of the Iranian Revolution, when the young Nigerian student, Ibrahim El-Zakzaky was influenced by the ideas of Khomeini and began to adopt the Shia ideology. According to counter-terrorism expert, Jacob Zenn, today El-Zakzaky is Iran's regime undisputed voice across Nigeria. El-Zakzaky's journey of advocating the ideas of Khomeini began when he was a student at Ahmadu Bello University in Zaria, Kaduna State and as such involved in Islamic movements of Nigeria in the seventies, like the Muslim Student Society and the Muslim Brotherhood. Inspired by the rise of Khomeini and the success of Iran's Islamic revolution, El-Zakzaky created the Islamic Movement of Nigeria. In the beginning years of the Iranian revolution, El-Zakzaky travelled regularly to Iran and adopted the rhetorical style of Iranian rulers, specifically Khomeini. Back home, he started to preach against imperialism of the West in Nigeria. He succeeded in mobilising people in northern parts of Nigeria to protest against a secular state, urging authorities to develop an Iranian-style Islamic Republic. ${ }^{100}$ El-Zakzaky also started recruiting young people for his Shia and pro-Iranian regime movement. He succeeded, in fact, in creating a huge Shia group in Nigeria and he transformed the Islamic Movement that begun as a student association to a well-structured organiscation equipped with welfare workers and armed gangs. ${ }^{101}$ El-Zakzaky recruited young students from northern Nigeria via lecture series about the Iranian revolution as an alternative model to

95 Egbewole and Hammed, "Curbing religious extremism of Boko Haram insurgency in Nigeria".

96 "Report of the Judicial Commission of Inquiry into the clashes between the Islamic Movement in Nigeria (IMN) and the Nigerian Army (NA) in Zaria, Kaduna State between Saturday 12th and Monday 14th December 2015", July 2016.

97 Hunter, Iran's Foreign Policy in the Post-Soviet Era: Resisting the New International Order.

98 Neriah, "Iranian Shiite Terror Cell in Nigeria Followed a Familiar Pattern".

99 Alami, "Hezbollah allegedly training Nigerian Shiites to expand influence in West Africa".

100 Zenn, “The Islamic Movement and Iranian Intelligence Activities in Nigeria".

101 Carmi, "Deconstructing and Countering the Iran Threat Network". 
secularism or socialism that were debated back in those days. In the years following the Islamic Revolution in Iran, he radicalised and opted for a "second jihad", simply meaning overthrowing the establishment. ${ }^{102}$

The Iranian regime and its forces responsible for spreading the revolution outward saw unprecedented opportunities in Africa. In this regard, El-Zakzaky's movement became Iran's most valuable and important "proxy" in Western Africa. ${ }^{103}$ The way for creating a state inside a state like in Lebanon was clearly paved by the fast growth of the Islamic Movement in Nigeria. ${ }^{104}$ Its members have committed large attacks on both foreign groups and Sunni Nigerians. Also, its members have been involved in spreading animus towards Christians and Jews. But what is alarming in this context is the continuous and systematic support of the Iranian regime for El-Zakzaky's movement. ${ }^{105}$ Although the Nigerian justice system does not hesitate to order heavy punishments for those who want to advance Iran's agenda in Nigeria, as it was the case with Mustapha Berende, who was found guilty by Justice Ahmed Ramat Mohammed in the Federal High Court of Abuja because of his active involvement in carrying out the terrorism agenda of Iran, ${ }^{106}$ it has not stopped Iran yet from rethinking its policies of interference in other nations. On the contrary, Iranian forces, such as the paramilitary Quds Force, is active along with Hezbollah in Nigeria. Both groups are involved in the spread and shipment of weapons to Nigeria. Those weapons were aimed at targeting the authorities as well as American and Israeli interests in the country. ${ }^{107}$ Hence, we can say that Iran has largely succeeded in its ambition to create a base in Nigeria, causing serious chaos to benefit its own political purposes of having some kind of hegemony in one of Africa's most important economies. ${ }^{108}$

\section{EXPORT OF REVOLUTION AND HUMAN FLOURISHING}

We will now turn to the question of what consequences exporting the revolution to Nigeria has on human flourishing. If we are to understand human flourishing as a normative concept about the good life, meaning satisfaction in life via having access to the very basic needs of life, such as security, health and welfare, ${ }^{109}$ then it does not need much elaboration to say why export of revolution is a serious obstacle

102 Zenn, “The Islamic Movement and Iranian Intelligence Activities in Nigeria”.

103 Zenn, "The Islamic Movement and Iranian Intelligence Activities in Nigeria" (quoting a former Iranian diplomat).

104 Clarke C and Smyth P. 2017. “The Implications of Iran's Expanding Shi 'a Foreign Fighter Network", CTC SENTINEL.

105 Zenn, "The Islamic Movement and Iranian Intelligence Activities in Nigeria".

106 Njoku P. 2018. "BREAKING: Court Convicts 2 Nigerian Terrorists", Independent, 24 January.

107 Zenn, "The Islamic Movement and Iranian Intelligence Activities in Nigeria".

108 Carmi, "Deconstructing and Countering the Iran Threat Network".

109 Barnett and Rasmussen, "The Right to Liberty in a Good Society". 
for human flourishing. However, we need to develop a strong argument. Because, much of what we have said about export of revolution is directly related to religious freedom. So, how can we find the kind of justification we are looking for in the concept of human flourishing to say that exporting the revolution is problematic and for that reason not a primary concern of religious freedom? What may help in this context is the object of export: the Iranian style of governance. As a matter of fact, Iran is an authoritarian theocracy, which over the past years has committed an uncountable amount of human rights violations. ${ }^{110}$ So, should we follow the example of Iran? For sure, not. If we truly believe in liberty for all without the kind of sectarian discrimination we face in Iran and amongst groups backed by Iran, ${ }^{111}$ then we have at least a basic normative argument to say that we reject the introduction of an Iranian style regime.

However, we also have a more empirical argument to be sceptical about the benefits of the implementation of an Iranian style revolution elsewhere. We have in the Nigerian situation an empirical argument to be afraid for much of what human flourishing stands for, namely the satisfaction of human beings desire for good security, prosperity and opportunities to reach a better life. ${ }^{112}$ The violence in Nigeria and the chaos caused by Iranian interference is in many ways contrary to the message behind human flourishing. Furthermore, it deprives people of the opportunity to make use of their basic capabilities as human beings in search of a better life. ${ }^{113}$ To put it differently, our hesitation for the export of revolution is embedded in important empirical arguments about chaos, insecurity and societal unrest, ${ }^{114}$ which help us to justify our rejection of the Iranian style revolution elsewhere.

But how shall we appraise the normative and the empirical arguments? Are we able to develop a more coherent argumentation pattern that can explain to us convincingly why we should have reservations about the export of revolution, generally and not uniquely from the perspective of human flourishing? In fact, we are so able operating at the intersection of law, religion and public policy. If we approach the export of revolution doctrine from a non-sectarian perspective, meaning opting for something opposite to the way in which Iran dispatches much of its internal and external affairs, then we may rely on how religion within the paradigm of liberal political philosophy. If you recall, our normative argument rejected the Iranian style governance because of its emphasis on sectarianism, which has caused much of the suffering people have faced inside and outside Iran. Hence, we end up for

110 See, for example, Ebadi S. 2009. “Islam, Human Rights, and Iran”, Emory International Law Review 23(1):13-24.

111 Abdo, The New Sectarianism.

112 Compare, for example, Barnett and Rasmussen, "The Right to Liberty in a Good Society".

113 See Zenn, "The Islamic Movement and Iranian Intelligence Activities in Nigeria".

114 On endangering the societal harmony due to Iranian conversion policies, see "Iran and the Shia legacy", Al Jazeera. 
this reason with non-sectarian theories of religious freedom that inform us about the "specialness" of religion for either a favoured or a disfavoured treatment in law. ${ }^{115}$

Basically, we can claim that liberal theories of religious freedom share a more general feature, that is: abstraction from the religious dimension, which means that religion qua religion does not warrant special legal solicitude. Religion is only a special via abstraction, meaning via the non-sectarian, protection-worthy categories that serve as proper liberal substitutes for the category of religion. ${ }^{116}$ This is due to the egalitarian approach of the liberal theories of religious freedom to theistic and non-theistic beliefs and the emphasis of these theories on neutrality towards any particular worldview. ${ }^{117}$

Abstraction manifests itself in refusing to justify religious freedom through appeals to religious values, thus rejecting the toleration of religion qua religion in (1) justifying free exercise by appealing to a more general framework of values that are not theistic per se, (2) insisting that justifications for religious exceptions, like for any other type of legal exception, need to be ecumenical - not in the religious meaning of the word, but rather in the sense of being widely accessible to a broad public, and (3) not because of the quality of people's beliefs but simply because they are human beings who share certain important features, such as conscience. ${ }^{118}$ Hence, the application of the abstraction theory to the case of export of revolution indicates that we are dealing with a serious security matter instead of a religious freedom case. Hence, following the recent recommendations made by the European Parliament in a draft report, it is not necessary to tolerate aggressive and intolerant religious expressions. ${ }^{119}$ The safety and security of human beings must prevail. Hence, it is necessary and important to monitor all the financial systems of groups that benefit from the export of revolution policies. ${ }^{120}$

Hence, abstraction from the religious dimension provides the philosophical underpinning for why we need to refrain from the adoption of an Iranian style of revolution or governance, given its high record of human rights abuses and failure in almost each aspect of showing good governance. Although one my rightly raise

115 See, generally, Wahedi S. 2018. "Abstraction from the religious dimension", Buffalo Human Rights Law Review 24:1-44.

116 For the development of this particular argument, I have benefitted tremendously from the feedback of professor Benjamin Berger on the theory of abstraction during my stay as visiting researcher at Osgoode Hall Law School in Toronto in April 2017.

117 For a discussion of the egalitarian theories of religious freedom, see Laborde C. 2015. "Liberal Neutrality, Religion and the Good?", in Cohen JL and Laborde C (eds). Religion, Secularism, and Constitutional Democracy. New York: Columbia University Press, 249.

118 Wahedi S. 2019. “The Health Law Implications of Ritual Circumcisions”, Quinnipiac Health Law Journal 22(2):39-75.

119 See Wahedi S. 2019. "Religious Freedom and Living Together", California Western International Law Journal (forthcoming 2019).

120 European Parliament. 2018. Draft report on findings and recommendations of the Special Committee on Terrorism (2018/2044(INI)). 
the point whether abstraction from the religious dimension that is mainly grounded in the liberal tradition is "applicable" in places that do not share the same narrative with African countries that may need to achieve freedom and democracy, we still may claim that, regardless of this latter more empirical argument, we have been able to provide a normative argumentation pattern that help us to say why we should not move towards Iran's style of governance or change of powers.

\section{CONCLUSION}

Like many other nations and regions, African countries with large Sunni Muslim populations face the challenges from the "export of revolution" doctrine. This theory entails the religious mobilisation of local people against their authorities. This "holy revolution" aims at a change of powers and maximisation of human flourishing via the establishment of justice, peace and welfare in society. The "export of revolution" doctrine was born shortly after the Iranian Revolution. Ayatollah Khomeini, the leader of the Iranian Revolution believed that other Muslim countries should follow the example of Iran for religious reasons. Immediately after the revolution, Iran funded political, economic and education projects to create local support for a new balance of powers in countries across Africa, Asia, the Middle East and the Balkans. An exemplary case is the rise and fall of the Islamic Movement in Nigeria. This movement, led by El-Zakzaky, succeeded in creating a large Shia minority in Nigeria, which hardly had any Shia in the past. African states consider Iranian conversion policies as interferences in internal affairs as these policies have resulted in the destabilisation of regions in Nigeria and Egypt. Although, the public discourse pays attention to such tensions, in the legal scholarship there is little known about the export of revolution doctrine and how it might affect human flourishing. This chapter has filled in this theoretical gap and set out why we should refrain from moving towards an Iranian style of governance or revolution That would not only harm human flourishing, but would also be a new tragedy in the history of mankind, given the huge record of human rights violations by Iranian authorities. 